\title{
In-vitro antimicrobial activity of different toothpastes
}

\section{Gautam B', Dongol E², Shrestha $A^{3}$}

'Bikram Gautam, Department of Microbiology, St. Xavier's College, Maitighar, Kathmandu, Nepal; ${ }^{2}$ Elisa Dongol, Department of Microbiology, St. Xavier's College, Maitighar, Kathmandu, Nepal; ${ }^{3}$ Anima Shrestha, Department of Microbiology, TriChandra Campus, Department of Microbiology, Kathmandu, Nepal

\begin{abstract}
Background: Tooth brushing with toothpaste is the most widely practiced form of oral hygiene. Toothpaste aids to improve oral hygiene and effective plaque removal. A wide range of chemicals, mainly antimicrobial agents, have been added to toothpastes which kill microorganisms by disrupting their cell walls and inhibiting their enzymatic activity. Objectives: The aim of the study was to determine the antimicrobial activity of toothpastes.

Methods: Eight (Two herbal and six regular) toothpastes were selected for the study. The study was conducted from October to November 2016 at St. Xavier's College's microbiology laboratory. Antimicrobial activity of toothpastes were assessed by measuring inhibition zones by broth dilution method and agar well diffusion method.

Results: Minimum Inhibitory Concentration determination by tube dilution method and cup well diffusion method was found to be same. The antimicrobial activity on test organisms was shown by all toothpastes (TH1, TH2, TR3, TR4, TR5, TR6, TR7 and TR8). Antimicrobial activity of all toothpastes were almost the same and was statistically significant ( $\mathrm{t}>0.05$ ) Conclusion: All eight toothpastes aids in lower microbial load. However, no toothpaste showed bactericidal and fungicidal effect against the tested microbes. The toothpaste containing only natural active ingredients were found to be more effective than the toothpaste containing chemical active agent followed by weaker antimicrobial effect given by the toothpaste containing both natural and chemical active ingredient as anantimicrobial agent.
\end{abstract}

Key words: Dilution, Minimum Bactericidal Concentration, Minimum Fungicidal Concentration, Minimum Inhibitory Concentration, Toothpaste

\section{INTRODUCTION}

T Toothpaste is classified as a drug and not as a cosmetic; as they contain(s) ingredients like sodium lauryl sulfate, sodium fluoride, Mentha spicata, Curcuma longa etc. to reduce microbial load. The main purpose of toothpaste is to reduce oral bacterial flora, deliver fluoride to teeth and contribute to dental health'1.

Dental caries is one of the most common chronic infectious diseases in the world which is characterized by a destruction of superficial dental structures, caused by acids which are by-products of carbohydrate metabolism by Streptococcus mutans; the primary species associated with the early dental caries process ${ }^{2}$. Bacterial plaque accumulated on dental surfaces are composed of native oral flora and these bacteria interact by various recognized ways including co-aggregation ${ }^{3}$,

Address for correspondence

Bikram Gautam

Department of Microbiology

St. Xavier's College

Maitighar, Kathmandu

E-mail: gautambikr@gmail.com metabolic exchange, cell-cell communication ${ }^{4}$, and exchange of genetic material ${ }^{5}$. These mechanisms benefit bacterial survival and can make dental biofilms difficult therapeutic targets in dental diseases.

Dental caries is the destruction of enamel, dentin or cementum of teeth due to bacterial activities, which if left untreated can cause considerable pain, discomfort, and high treatment costs ${ }^{2}$. The prevalence and incidence of oral diseases usually associated with social and economic implications ${ }^{6}$.

Tooth brushing is ubiquitously performed all over the globe which aids in improving oral hygiene and effective plaque removal ${ }^{7}$. Tooth brushing with toothpaste is the most widely practiced form of oral hygiene ${ }^{3}$. The success of any toothpaste lies in its ability to eliminate pathogenic oral micro-flora. Fluoride dentifrices have been widely used all over the world and extensive research has established their abilities in terms of caries resistance ${ }^{7}$. A wide range of chemicals, mainly antimicrobial agents, have been added to toothpastes in order to produce a direct inhibitory effect on plaque formation ${ }^{8,4}$. 
The addition of antimicrobial agents improves the efficacy of mechanical tooth-cleaning procedures ${ }^{4}$; aiding the control of dental plaque and prevents dental caries and periodontal diseases ${ }^{7,9}$. When these anti-microbial agents are added to the oral products, they kill microorganisms by disrupting their cell walls and inhibiting their enzymatic activity. They prevent bacterial aggregation, the release of endotoxins and affects multiplication ${ }^{7,10}$.

The aims of the study were to determine the antimicrobial activity of the toothpaste, determine Minimum Inhibitory Concentration, Minimum Bactericidal Concentration and Minimum Fungicidal Concentration of the toothpastes.

\section{METHODOLOGY}

\section{STUDY SITE AND DURATION}

The study was conducted at Department of Microbiology, St. Xavier's College's, Maitighar, Kathmandu, Nepal from October 30 to November 30, 2016.

\section{TEST MICROORGANISMS}

American Type Culture Collection (ATCC) culture of common oral micro-flora and possible contamination in brush ${ }^{11}$ were acquired from National Public Health Laboratory (NPHL), Teku, Kathmandu.

\section{SELECTED TOOTHPASTES}

Eight toothpastes were selected for the study. Among these, two were herbal and six were regular. The products were bought from the local market, Kathmandu.

\section{DILUTION OF TOOTHPASTE}

Toothpastes were diluted in 1:1, 1:2, 1:4, 1:8 ratio (toothpaste: sterile distilled water).

\section{PREPARATION OF MCFARLAND STANDARD (0.5)}

$0.5 \mathrm{ml}$ of $0.048 \mathrm{M} \mathrm{BaCl}_{2}\left(1.17 \% \mathrm{w} / \mathrm{v} \mathrm{BaCl} \cdot \mathrm{H}_{2} \mathrm{O}\right)$ was added to $99.5 \mathrm{ml}$ of $0.18 \mathrm{M} \mathrm{H}_{2} \mathrm{SO}_{4}(1 \% \mathrm{w} / \mathrm{v})$ with constant stirring. The McFarland standard was thoroughly mixed to ensure that it was evenly suspended. Its absorbance was measured in a cuvette with $1 \mathrm{~cm}$ light path (water as blank) absorbance was measured at awavelength of $625 \mathrm{~nm}$. 0.08 to 0.13 was the acceptable range for the McFarland standard.

\section{DETERMINING THE MICROBIAL LOAD OF TEST ORGANISM}

The incubated nutrient broth was tallied with 0.5 McFarland standard solution to determine the microbial load as $150 \times 10^{6}$.

\section{SEEDING IN TOOTHPASTE DILUTIONS}

From the 0.5 McFarland tallied broth $1 \mathrm{ml}$ broth was inoculated with 1:1 toothpaste dilution. Sterile distilled water was inoculated in control tubes.

\section{MINIMAL INHIBITORY CONCENTRATION (MIC)}

The MIC is the lowest concentration of antibiotics that will inhibit the growth of microbial strains ${ }^{17}$. The MIC were determined by broth macro-dilution method using Mueller Hinton broth, different concentration of toothpaste $(1: 1,1: 2,1: 4,1: 8)$ were prepared and tested against microbes of Table 1.

Determined microbial load of test organisms were seeded to the tubes of all dilutions. The same procedure was performed with sterile distilled water (as control). The contents of the tubes were mixed thoroughly and incubated at $37^{\circ} \mathrm{C}$ for 24 hours (except for Candida albicans which was incubated at $27^{\circ} \mathrm{C}$ for 3 days).

The MIC endpoint was taken as the tube which didn't show visible turbidity. This MIC was confirmed by agar well diffusion method.

\section{AGAR WELL DIFFUSION METHOD OF CONFIRMING MIC}

The MIC of different concentrations of the dentifrices was determined by agar well diffusion method. Lawn culture of the test organisms were made on the Muller Hinton agar plates using asterile cotton swab and the plates were dried for 15 minutes. Dentifrice dilutions of different concentrations (1:1, 1:2, 1:4, and 1:8) were introduced into each of the wells along with control (sterile distilled water). The plates were incubated at $37^{\circ} \mathrm{C}$ for 24 hours. The antimicrobial activity was evaluated by measuring the diameter of zones of inhibition ( $\mathrm{mm}$ ).

The MIC endpoint was taken as the well which gave on the zone of inhibition at minimum concentration.

\section{MINIMAL BACTERICIDAL CONCENTRATION (MBC)}

Tubes in which no visible bacterial growth and the dilution where visible microbial growth was seen were sub-cultured in basal media (toothpaste free nutrient agar and incubated overnight at $37^{\circ} \mathrm{C}$ ).

The MBC endpoint was taken as where microbial growth did not occur on the basal media.

\section{MINIMAL FUNGICIDAL CONCENTRATION (MFC)}

Tubes in which no visible bacterial growth and the dilution where visible microbial growth occurredwere sub-cultured in basal media (toothpaste free potato 


\section{Table 1: Toothpaste and microorganisms used in the study}

\begin{tabular}{|cll|}
\hline S. No & Toothpaste and their active ingredient(s) & Microorganisms \\
\hline 1 & TH1 -Mentha spicata, Curcuma longa & \\
\hline 2 & TH2 -Sunthi, Allium sativum, Pudinasatva, Piper nigrum & Lactobacillus spp, Candida albicans, \\
\hline 3 & TR3 -Triclosan & Staphylococcus aureus, Staphylococcus \\
\hline 4 & TR4 - Sodium lauryl sulfate & epidermidis, Pseudomonas aeruginosa, \\
\hline 5 & TR5 - Sodium lauryl sulfate, Sodium fluoride & Escherichia coli \\
\hline 6 & TR6 - Mentha spicata, Curcuma longa, Piper sylvaticum, Sodium benzoate & \\
\hline 7 & TH7 -Sodium lauryl sulfate, Calcium fluoride, Thymol & \\
\hline 8 & TH8 - Sodium lauryl sulfate, Citrus aurantifolia & \\
\hline
\end{tabular}

dextrose agar). All tubes in which no visible bacterial growth was observed were sub-cultured in basal media. The plates were then incubated for 3 days at $27^{\circ} \mathrm{C}$.

The MFC endpoint was taken as where microbial growth did not occur on the basal media.

\section{RESULTS}

The MIC, MBC and MFC of toothpastes are shown in figure 1, 2; 3 and 4 respectively. The results indicated that all tested toothpastes demonstrated a significant antimicrobial activity against the tested microorganisms, and the control showed no activity. Antimicrobial activity of all toothpastes on the test organisms werealmost the same and was statistically significant ( $t>0.05)$. MIC determination by tube dilution method and cup well diffusion method was found to be same. MIC determination by tube dilution method and cup well diffusion method was found to be same. The highest antimicrobial activity on test organism was shown by the herbal toothpastes (TH1, $\mathrm{TH} 2)$ and regular toothpastes (TR3, TR4), while regular toothpastes TR5, TR6 showed weak antimicrobial activity. The antimicrobial activity of regular toothpaste TR7 and TR8 also showed a weaker activity compared to regular $\mathrm{TH} 1, \mathrm{TH} 2$ and herbal toothpastes. The results of MIC are given in table 2. All toothpastes were found to have no bactericidal and fungicidal property.

MIC at 1:4 was observed in 3 toothpastes $\mathrm{TH} 1, \mathrm{TH} 2$ and TR3 while toothpastes TR4, TR5 and TR6 showed MIC at 1:2 against Lactobacillus spp, C. albicans, E. coli, S. aureus and S. epidermidis. All the toothpaste showed MIC at 1:2 against $P$. aeruginosa.

\section{Table 2: Minimal inhibitory concentration test's result}

\begin{tabular}{|c|c|c|c|c|c|c|c|}
\hline S. No & Toothpaste & Test organism & 1:1 & $1: 2$ & $1: 4$ & $1: 8$ & MIC \\
\hline \multirow{8}{*}{1} & $\mathrm{TH} 1$ & \multirow{8}{*}{ Lactobacillus spp } & - & - & - & + & $1: 4$ \\
\hline & $\mathrm{TH} 2$ & & - & - & - & + & $1: 4$ \\
\hline & TR3 & & - & - & - & + & $1: 4$ \\
\hline & TR4 & & - & - & - & + & $1: 4$ \\
\hline & TR5 & & - & - & - & + & $1: 4$ \\
\hline & TR6 & & - & - & - & + & $1: 4$ \\
\hline & TR7 & & - & - & - & + & $1: 4$ \\
\hline & TR8 & & - & - & - & + & $1: 4$ \\
\hline \multirow{8}{*}{2} & $\mathrm{TH} 1$ & \multirow{8}{*}{ Candida albicans } & - & - & - & + & $1: 4$ \\
\hline & $\mathrm{TH} 2$ & & - & - & - & + & $1: 4$ \\
\hline & TR3 & & - & - & - & + & $1: 4$ \\
\hline & TR4 & & - & - & - & + & $1: 4$ \\
\hline & TR5 & & - & - & + & + & $1: 2$ \\
\hline & TR6 & & - & - & + & + & $1: 2$ \\
\hline & TR7 & & - & - & + & + & $1: 2$ \\
\hline & TR8 & & - & - & + & + & $1: 2$ \\
\hline
\end{tabular}




\begin{tabular}{|c|c|c|c|c|c|c|c|}
\hline \multirow{8}{*}{3} & TH1 & \multirow{8}{*}{ Escherichia coli } & - & - & - & + & $1: 4$ \\
\hline & $\mathrm{TH} 2$ & & - & - & - & + & $1: 4$ \\
\hline & TR3 & & - & - & - & + & $1: 4$ \\
\hline & TR4 & & - & - & - & + & $1: 4$ \\
\hline & TR5 & & - & - & + & + & $1: 2$ \\
\hline & TR6 & & - & - & + & + & $1: 2$ \\
\hline & TR7 & & - & - & + & + & $1: 2$ \\
\hline & TR8 & & - & - & + & + & $1: 2$ \\
\hline \multirow{8}{*}{4} & TH1 & \multirow{8}{*}{ Pseudomonas aeruginosa } & - & - & + & + & $1: 2$ \\
\hline & $\mathrm{TH} 2$ & & - & - & + & + & $1: 2$ \\
\hline & TR3 & & - & - & + & + & $1: 2$ \\
\hline & TR4 & & - & - & + & + & $1: 2$ \\
\hline & TR5 & & - & - & + & + & $1: 2$ \\
\hline & TR6 & & - & - & + & + & $1: 2$ \\
\hline & TR7 & & - & - & + & + & $1: 2$ \\
\hline & TR8 & & - & - & + & + & $1: 2$ \\
\hline \multirow{8}{*}{5} & TH1 & \multirow{8}{*}{ Staphylococcus epidermidis } & - & - & - & + & $1: 4$ \\
\hline & TH2 & & - & - & - & + & $1: 4$ \\
\hline & TR3 & & - & - & - & + & $1: 4$ \\
\hline & TR4 & & - & - & - & + & $1: 4$ \\
\hline & TR5 & & - & - & + & + & $1: 2$ \\
\hline & TR6 & & - & - & + & + & $1: 2$ \\
\hline & TR7 & & - & - & + & + & $1: 2$ \\
\hline & TR8 & & - & - & + & + & $1: 2$ \\
\hline \multirow{8}{*}{6} & TH1 & \multirow{8}{*}{ Staphylococcus aureus } & - & - & - & + & $1: 4$ \\
\hline & TH2 & & - & - & - & + & $1: 4$ \\
\hline & TR3 & & - & - & - & + & $1: 4$ \\
\hline & TR4 & & - & - & - & + & $1: 4$ \\
\hline & TR5 & & - & - & + & + & $1: 2$ \\
\hline & TR6 & & - & - & + & + & $1: 2$ \\
\hline & TR7 & & - & - & + & + & $1: 2$ \\
\hline & TR8 & & - & - & + & + & $1: 2$ \\
\hline
\end{tabular}

In case of tube dilution method: "-" = visible turbidity not observed and "+" = visible turbidity observed

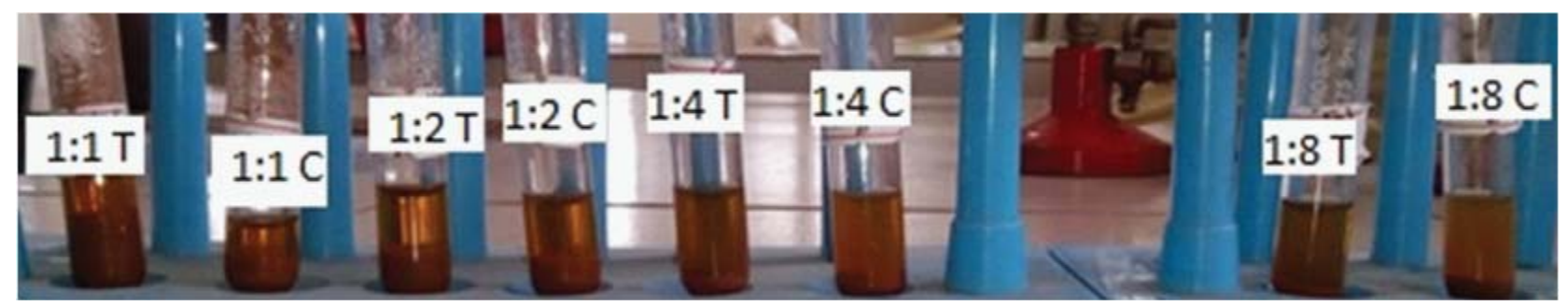

Figure 1: MIC of herbal toothpaste

T2 toothpaste's action against Candida albicans; showing turbidity at dilution 1:8 only 


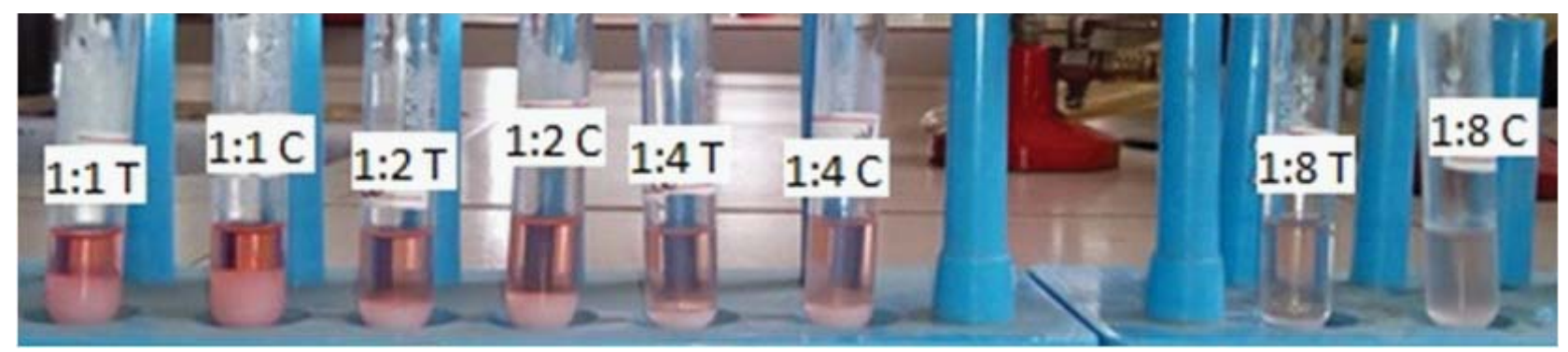

Figure 2: MIC of regular toothpaste

TH3 toothpaste's action against Staphylococcal aureus showing turbidity at dilution 1:8 only

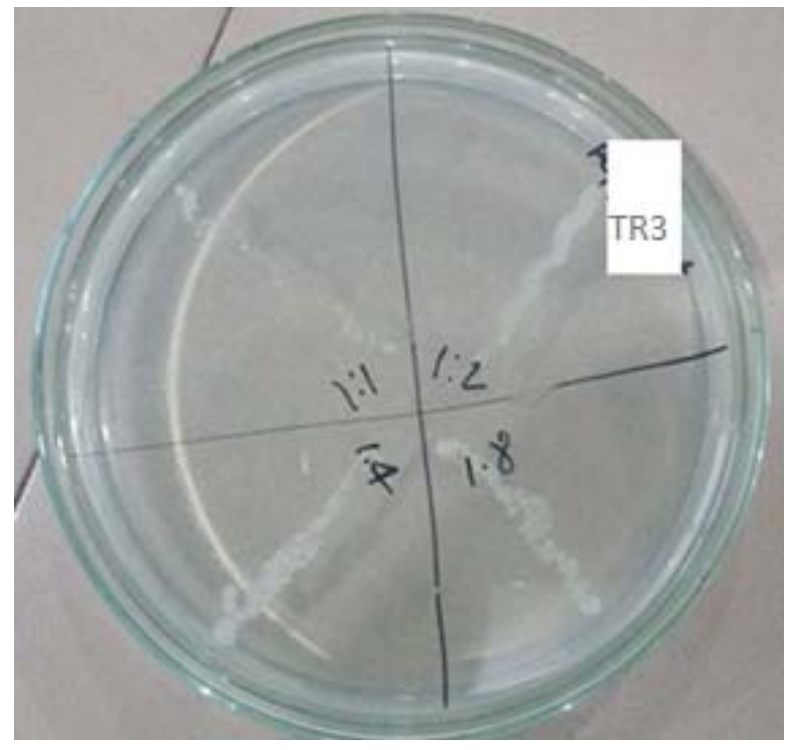

Figure 3: MBC of toothpaste

Toothpaste TR3's MBC result which shows that the toothpaste had no anti-bactericidal activity against E. coli

\section{DISCUSSION}

MIC at 1:4 was observed in 3 toothpastes $\mathrm{TH} 1, \mathrm{TH} 2$ and TR3 while toothpastes TR4, TR5, TR6, TR7 and TR8 showed MIC at 1:2 against Lactobacillus spp, C. albicans, E. coli, S. aureus and S. epidermidis. All toothpastes showed MIC at 1:2 against $P$. aeruginosa. Both tube dilution method and modified cup well diffusion method to determine MIC showed same results for similar dilutions. This implies that the toothpaste is efficient in inhibiting visible microbial growth only but may not necessarily kill all the microbes.

In the study of Nayak et al (2010) the Candida albicans was found to be sensitive even at $2 \mathrm{mg} / \mathrm{ml}$ concentration of the toothpaste containing Ganoderma lucidum. This could be due to the fact that the antimicrobial agent in their study was Ganoderma lucidum while the natural antimicrobial agents in the selected toothpaste for the study contained Mentha spicata, Curcuma longa,

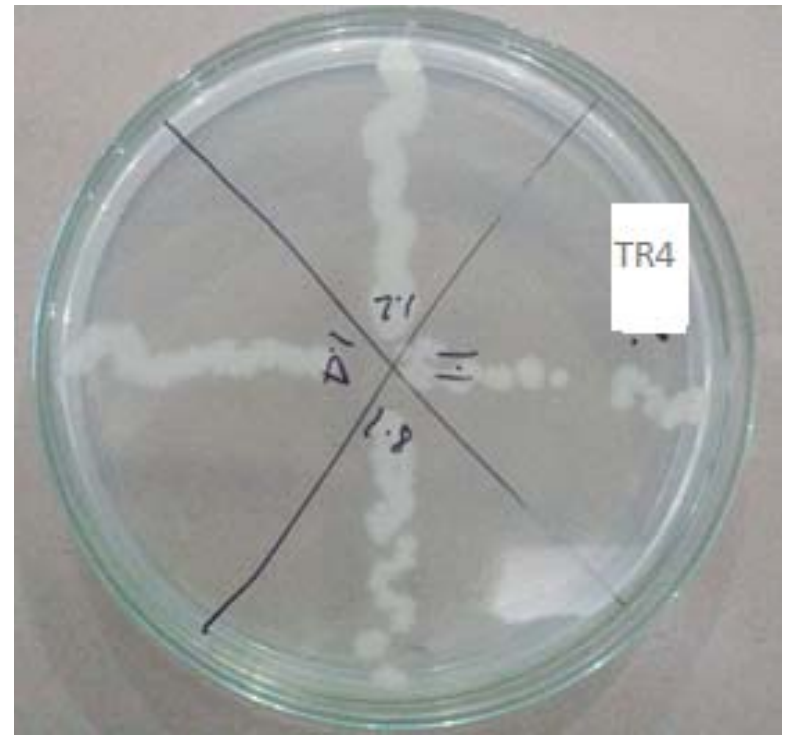

Figure 4: MFC of toothpaste

Toothpaste TR4's MFC result which shows that the toothpaste had no anti-fungicidal activity against Candida albicans

Sunthi, Allium sativum, Pudina satva, Piper nigrum, Piper sylvaticum and Citrus aurantifolia; and the chemical antimicrobial agents in the selected toothpaste for the study contained triclosan, sodium lauryl sulphate, sodium fluoride, calcium fluoride, sodium benzoate.

In the study by Maripandi et al (2011) the highest inhibition zone against Streptococcus spp was given by pepsodent followed by colgate followed by close up followed by dabor babool. The toothpaste they selected were colgate which contained sodium fluoride and triclosan, pepsodent which contained sodium fluoride, close up contained sodium fluoride and triclosan; and dabor babool which contained Piper nigram, P. langum, Zingiber officinale, Cinnamomum camphora, Menthos spicate. One of the reason for the disagreement of this study with their study might be due to different test organism(s) used in the study. 
The study conducted by de Rossi et al (2014) also reached the same conclusion as to this study where better antimicrobial activity performed in in-vitro was shown by herbal based toothpaste. Their selected toothpaste Parodontax containing Echinacea angustifolia, Commiphora myrrha, Krameria triandra, Matricaria chamomilla which showed better antimicrobial agents against Pseudomonas aeruginosa followed by toothpaste Sanogil; containing Sodium lauryl sulfate and triclosan followed by toothpaste Cariax gingival containing sodium fluoride which are the same active ingredients of the regular toothpaste selected for this toothpaste.

This implies that just like MIC results, MBC and MFC show that all toothpastes reduce microbial load but do not eliminate all microorganisms.

The result didn't agree with an in-vitro effectiveness study by Kurian and R.V (2015) where fluoride toothpaste containing triclosan was found superior followed by the herbal toothpaste containing alkaloids, flavonoids, polyphenols and lectins.

\section{REFERENCES}

1. World Health Organization. Appropriate use of fluoride for human health. Geneva. WHO report; 2003.

2. Kurian M, R.V. G. Effect of herbal and fluoride toothpaste on Streptococcus mutans - A comparative study. J. Pharm. Sci. \& Res. 2015;7(10):864-865.

3. Peterson PE. "World Oral Health Report 2003". Oral Health Programme Non-Communicable Disease Prevention and Health Promotion. Geneva, Switerland. World Health Organization; 2003.

4. Pannuti CM, Mattos JP, Ranoya PN, Jesus AM, Lotufo RF, Romito GA. Clinical effect of a herbal dentifrice on the control of plaque and gingivitis: a doubleblind study. Pesqui. Odontol. Bras. 2003;17(4):314-8.

5. Lee SS, Zhang W, Li Y. The antimicrobial potential of 14 natural herbal dentifrices: results of an in vitro diffusion method study. J Am Dent Assoc. 2004; 135(8):1133-41.

6. Nayak A, Nayak RN, Bhat K. Antifungal activity of a toothpaste containing Ganoderma lucidum against - an in vitro study. J Int Oral Health 2010;2(2):51-57.

7. Ozaki F, Pannuti CM, Imbronito AV, Pessotti W, Saraiva $L$, de Freitas NM et al. Efficacy of a herbal toothpaste on patients with established gingivitis a randomized controlled trial. Braz Oral Res 2006;20(2):172-7.
Most commonly used and recommended by the WHO are fluoride and triclosan'. But the excess use of fluoride can cause dental fluorosis so the recommended amount of the fluoride should be used in parts per million as an ingredient in the toothpaste'.

\section{CONCLUSION}

Hence, from the study, it is concluded that all toothpastes aids to lower microbial load. However, no toothpaste showed the bactericidal and fungicidal effect against the tested microbes. The toothpaste containing only natural active ingredients were found to be more effective than the toothpaste containing chemical active agent followed by weaker antimicrobial effect given by the toothpaste containing both natural and chemical active ingredient as anantimicrobial agent.

\section{ACKNOWLEDGEMENT}

Special thanks goes to Mr. Sudhakar Pant, HOD, Department of Microbiology, St. Xavier's College, Maitighar, Kathmandu, Nepal and Mr. Anup Basnet for his expertise in Biochemistry.

8. Fine DH, Furgang D, Markowitz K, Sreenivasan PK, Klimpel K, de Vizio W. The antimicrobial effect of a triclosan/copolymer dentifrice on oral microorganisms in vivo. J Am Dent Assoc. 2006;137(10):1406-13.

9. Davies RM, Ellwood RP, Davies GM. The effectiveness of a toothpaste containing triclosan and polyvinylmethyl ether maleic acid copolymer in improving plaque control and gingival health: a systematic review. J Clin Periodontol. 2004;31(12):1029-1033.

10. Bou-Chacra NA, Gobi SS, Ohara MT, Pinto TJA. Antimicrobial activity of four different dental gel formulas on cariogenic bacteria evaluated using the linear regression method: RevistaBrasileira de CiênciasFarmacêuticas. 2005;41(3):323-31.

11. Samuel $\mathrm{O}$, Ifeanyi $\mathrm{O}$. Bacterial contamination of used manual toothbrushes obtained from some students of Nnamdi Azikiwe University Awka, Nigeria. Universal Journal of Microbiology Research. 2015;3(4):56-59.

12. Herrera D, Roldan S, Santacruz I, Santos S, Masdevall $M$, Sanz M. Differences in antimicrobial activity of four commercial $0.12 \%$ chlor-hexidine mouthrinse formulations: an in vitro contact test and salivary bacterial counts study. J Clin Periodontol. 2003;30(4):307-14.

13. Moran J M, Addy M, Newcombe R G, Marlow I, A study to assess the plaque inhibitory action of 
a newly formulated triclosan toothpaste. J Clin Periodontol. 2001;28(1):86-90.

14. Cheesbrough M. Medical Laboratory Manual for Tropical Countries Vol. 2. $1^{\text {st }}$ edition. India. Butterworth and Co (Publishers) Ltd. 1984; 227-332.

15. Jabbarifar SE, Tabibian SA, Poursina F. Effect of fluoride mouth rinse and toothpaste on number of streptococcal colony forming units of dental plaque. 2005;1-8.

16. Maripandi AT, Kumar AT, Salamah AAA. Prevalence of dental caries bacterial pathogens and evaluation of inhibitory concentration effect on different toothpastes against Streptococcus spp. African Journal of Microbiology Research. 2011;5(14):17778-1783.

17. British Pharmacopoeia. The department of health. British Pharmacopoeia Commission, London. The stationary office. 1999;121-125.

18. de Rossi A, Ferreira DCA, da Silva RAB, de Queiroz $A M$, da Silva Léa $A B$, Nelson-Filho P. Antimicrobial activity of toothpastes containing natural extracts, chlorhexidine or triclosan, Brazilian Dental Journal.2014; 25:186. 